\title{
Efektivitas dan Keamanan Kombinasi Terfenadin dan Pseudoefedrin pada Anak Rinitis Alergika
}

\author{
Nahrawi, Zakiudin Munasir, ${ }^{*}$ Abdul Latief** \\ Divisi Alergi Imunologi Departemen Ilmu Kesehatan Anak Fakultas Kedokteran Universitas Indonesia \\ RS Dr. Cipto Mangunkusumo Jakarta
}

\begin{abstract}
Latar belakang. Kombinasi terfenadin dan pseudoefedrin telah terbukti efektif mengatasi rinitis alergika tetapi sejak diketahui efek kardiotoksik terfenadin, diperlukan penilaian lanjutan keamanannya pada anak.

Tujuan. Mengetahui tingkat keamanan dan efektivitas kombinasi terfenadin dan pseudoefedrin pada anak rinitis alergika.

Metode. Penelitian open trial, tanpa kontrol dengan desain before and after. Pasien rinitis alergika dengan elektrokardiografi (EKG) normal, diberikan pengobatan kombinasi terfenadin dan pseudoefedrin 5 hari, kemudian penilaian gejala klinis, reaksi simpang dan EKG ulang pasca pengobatan.

Hasil.: Lima puluh empat pasien (70,1\%) dengan skala penilaian pengobatan baik, 20 (26\%) dengan skala sangat baik, dan tidak ditemukan perburukan. Tidak ditemukan perbedaan interval Q-T dan Q-Tc sebelum (0,33 detik dan 0,41 detik) dan sesudah pengobatan (0,33 detik dan 0,41 detik). Pada sebagian besar pasien $(\mathbf{9 4 , 8 \% )}$ tidak dijumpai reaksi simpang.

Kesimpulan. Kombinasi terfenadin dan pseudoefedrin pada anak rinitis alergika terbukti aman dan efektif. Sebagian besar pasien tidak ditemukan reaksi simpang dan tidak ditemukan dampak kardiotoksik.(Sari Pediatri 2008; 9(5):299-303).
\end{abstract}

Kata kunci: rinitis alergika, kardiotoksik, terfenadin, pseudoefedrin.

$\mathrm{R}$

initis alergika adalah suatu kelainan gejala hidung yang diinduksi oleh paparan alergen sehingga terjadi inflamasi membran nasalis yang diperantarai IgE. Karakteristik klinis

\footnotetext{
Alamat korespondensi

Dr. Zakiudin Munasir, SpA(K), Divisi Alergi Imunologi Departemen Ilmu Kesehatan Anak FKUI-RSCM, Jl. Salemba 6, Jakarta 10430.

Telepon: 021-3161144, Fax.: 021-3913982.
}

rinitis alergika adalah bersin, hidung tersumbat, beringus, dan gatal di hidung. ${ }^{1}$ Antihistamin H1 generasi kedua (terfenadin) saat ini digunakan secara luas dan dilaporkan mempunyai efektivitas untuk mengatasi gejala klinis rinitis alergika.,3 Terfenadin merupakan salah satu antihistamin $\mathrm{H} 1$ yang banyak diteliti karena memiliki awitan aksi dan efikasi yang lebih baik dibandingkan obat lain pada golongan yang sama. ${ }^{4}$ Terfenadin efektif dalam mengurangi gejala bersin, rasa gatal, dan beringus, tetapi kurang dalam 
menghilangkan gejala hidung tersumbat. ${ }^{2}$ Dekongestan (pseudoefedrin) dapat mengatasi hidung tersumbat. ${ }^{5,6}$ Melihat kelemahan masing-masing obat tersebut telah dilakukan penelitian mengenai efektivitas kombinasi antihistamin dengan dekongestan. Beberapa peneliti melaporkan tentang manfaat kombinasi antihistamin dan dekongestan yang lebih baik dibandingkan pemakaian tunggal. ${ }^{7-11}$

Di Amerika Serikat tahun 1990 dilaporkan reaksi simpang yang serius dihubungkan dengan pemberian terfenadin berupa gangguan irama jantung (torsades de pointes). ${ }^{12}$ Penelitian lain juga melaporkan bahwa terfenadin bila diberikan bersamaan dengan pemberian antibiotik golongan makrolid dan anti jamur akan ditemukan pemanjangan interval Q-T dan Q-Tc, namun tidak ditemukan gangguan kardiotoksik dengan pemakaian tunggal. ${ }^{13,14}$

Kombinasi terfenadin dan pseudoefedrin mempunyai peran penting dalam menyembuhkan gejala rinitis alergika. Sejak diketahui efek toksisitas terhadap jantung yang berhubungan dengan pemberian terfenadin, diperlukan penilaian lanjutan terhadap jantung.

\section{Metode}

Penelitian open trial tanpa kontrol dengan desain before and after. Penelitian dilakukan di Poliklinik Alergi Imunologi Departemen Ilmu Kesehatan Anak RSUPN dr. Cipto Mangunkusumo (RSCM) dan praktek swasta dokter spesialis anak di Jakarta. Pelaksanaan penelitian dimulai bulan September 2006 dan berakhir April 2007. Populasi terjangkau adalah semua pasien rinitis alergika yang berusia 6-15 tahun dan berobat ke Poliklinik Alergi Imunologi Departemen Ilmu Kesehatan Anak RSCM dan praktek swasta dokter spesialis anak di Jakarta. Sampel penelitian adalah semua anak pada populasi terjangkau yang memenuhi kriteria inklusi yaitu berusia 6-15 tahun. Pasien atau orang tua pasien menyetujui dan menandatangani formulir informed consent dan bersedia untuk mencatat perkembangan gejala klinis dan reaksi simpang yang terjadi. Pasien dengan diagnosis rinitis alergika pada saat datang berobat dengan gejala beringus, bersin, hidung tersumbat, dan gatal di hidung (diagnosis ditegakkan oleh konsultan Divisi Alergi Imunologi), pemeriksaan EKG dalam batas normal. Pasien sedang menderita kelainan atau penyakit hati dengan gejala klinis yang nyata, pasien sedang dalam pengobatan obat antagonis reseptor $(\mathrm{H} 1$ untuk generasi pertama 3 hari dan untuk generasi ke dua 1 minggu sebelum penelitian), pengobatan kortikosteroid sistemik, pengobatan anti jamur (ketokonazol, flukonazol, Itrakonazol, metronidazol, mikonazol), antibiotik golongan makrolid, dan kuinin, riwayat interval Q-Tc memanjang, ikut dalam penelitian lain yang menyangkut obat yang diteliti, diketahui tersangka alergi terhadap obat penelitian, tidak diikutsertakan dalam penelitian.

Subjek yang memenuhi kriteria penelitian, saat kunjungan pertama diminta menandatangani formulir informed consent. Seluruh pasien yang ikut serta dalam penelitian dilakukan pemeriksaan fisis, pemeriksaan EKG, penilaian gejala klinis menggunakan skor pada setiap kunjungan (awal adalah kunjungan ke-1 dan kunjungan ke-2 adalah akhir penelitian). Skor dari parameter gejala klinis adalah skor 0: tidak ada gejala, skor 1: ringan, skor 2: sedang, skor 3: berat. Setelah selesai pemeriksaan, pasien diberikan pengobatan selama 5 hari dengan suspensi kombinasi terfenadin dan pseudoefedrin. Dosis untuk usia 6-12 tahun 3 x 5 $\mathrm{ml}$ (berisi suspensi kombinasi terfenadin $20 \mathrm{mg}$ dan pseudoefedrin $15 \mathrm{mg}$ ) dan untuk usia 13-15 tahun 3 x $10 \mathrm{ml}$ (berisi suspensi kombinasi terfenadin $40 \mathrm{mg}$ dan pseudoefedrin $30 \mathrm{mg}$ ).

Kunjungan ke-2 ditetapkan 5 hari setelah kunjungan ke-1. Saat kunjungan ke-2 dilakukan pemeriksaan fisis, penilaian efektivitas dengan mempergunakan skala 1-4 (1: sangat baik, 2: baik, 3: cukup, 4: buruk) dari persentase penurunan skor total setelah mendapatkan pengobatan (selama 5 hari) dibandingkan sebelum mendapat pengobatan dan penilaian keamanan evaluasi pemeriksaan EKG ulang pasca pengobatan (terutama interval Q-Tdan Q-Tc) dan evaluasi reaksi simpang lain dari obat penelitian (reaksi alergi).

Data diolah mempergunakan program SPSS 12. Data deskriptif disajikan secara tekstular dan tabular. Perhitungan sebaran data dengan menggunakan perhitungan koefisien varian.

\section{Hasil}

Terdapat 77 anak yang memenuhi kriteria penelitian, 47 (61\%) anak laki-laki, 30 (39\%) anak perempuan, dan median usia pasien pada penelitian ini adalah 8 tahun dengan kisaran 6-15 tahun. 
Koefisien varian menurut data umur 29,32\%, skor total sebelum pengobatan $37,38 \%$ sesudah pengobatan $76,33 \%$, dan persentase skor total 29,25\%. Sebaran data menurut umur, total skor dan menurut penurunan persentase skor total tidak normal karena nilai koefisien varian $>20 \%$, sehingga nilai yang digunakan adalah nilai median dan kisaran.

Jika dinilai secara deskriptif tampak penurunan nilai total skor antara sebelum dan sesudah pengobatan yaitu dari 6 menjadi 2 (Tabel 1), dan penurunan persentase total skor sebelum dan sesudah pengobatan adalah $75 \%$, dengan kisaran 17\%-100\%. Penurunan total skor atau penurunan persentase total skor dari penilaian gejala klinis, menunjukan adanya perubahan (perbaikan) gejala klinis sesudah pengobatan.

Sebagian besar pasien $(70,1 \%)$ memiliki skala penilaian hasil pengobatan baik dan $26 \%$ memiliki skala sangat baik, tidak ada pasien yang mengalami perburukan (Tabel 2). Berdasarkan persentase pasien yang memenuhi skala penilaian hasil pengobatan sangat baik dan baik yaitu $96,1 \%$, hasil pengobatan ini dapat dikatakan efektif ( $>72 \%$ ).

Koefisien varian menurut data interval Q-T dan Q-Tc sebelum pengobatan adalah 7,57\%, dan 4,39\%, sedangkan sesudah pengobatan adalah $8,18 \%$ dan $4,87 \%$. Sebaran data menurut data interval Q-T dan Q-Tc adalah normal karena nilai koefisien varian $<20 \%$, sehingga nilai yang digunakan adalah nilai rerata dan stándar deviasi.

Tidak terdapat perbedaan hasil pemeriksaan EKG didapatkan interval Q-T antara sebelum dan sesudah pengobatan. Setelah dikoreksi terhadap frekuensi jantung dengan menggunakan rumus Bazett, ternyata tidak ditemukan perbedaan pada interval Q-Tc antara sebelum dan sesudah pengobatan (Tabel.3).

Tabel 1. Total skor sebelum dan sesudah pengobatan

\begin{tabular}{lcc}
\hline & Median & Kisaran \\
\hline Sebelum pengobatan & 6 & $4,00-19,00$ \\
Sesudah pengobatan & 2 & $0,00-8,00$ \\
\hline
\end{tabular}

Tabel 2. Evaluasi skala penilaian hasil pengobatan

\begin{tabular}{lcc}
\hline Hasil pengobatan & Jumlah $(\mathrm{n}=77)$ & $\%$ \\
\hline Sangat baik & 20 & 26 \\
Baik & 54 & 70,1 \\
Cukup & 3 & 3,9 \\
Buruk & 0 & 0 \\
\hline
\end{tabular}

Tabel 3. Perbandingan interval Q-T dan Q-Tc antara sebelum dan sesudah pengobatan

\begin{tabular}{lcccc}
\hline & $\begin{array}{c}\text { Interval } \\
\text { Rerata (detik) }\end{array}$ & $\begin{array}{c}\text { Q-T } \\
\text { SD }\end{array}$ & $\begin{array}{c}\text { Interval } \\
\text { Rerata (detik) }\end{array}$ & $\begin{array}{c}\text { Q-Tc } \\
\text { SD }\end{array}$ \\
\hline Penilaian & 0,33 & 0,025 & 0,41 & 0,018 \\
Sebelum pengobatan & 0,33 & 0,027 & 0,41 & 0,020 \\
\hline
\end{tabular}

Tabel 4. Reaksi simpang lain

\begin{tabular}{lcc}
\hline Reaksi simpang & Jumlah $(\mathrm{n}=77)$ & $\%$ \\
\hline Mual & 1 & 1,3 \\
Mulut kering & 2 & 2,6 \\
Pusing & 1 & 1,3 \\
Tidak ada keluhan & 73 & 94,8 \\
\hline
\end{tabular}

Reaksi simpang lain yang ditemukan selama pengobatan yaitu mual 1 anak (1,3\%), mulut kering $2(2,6 \%)$ dan pusing $1(1,3 \%)$. Sebagian besar pasien $(94,8 \%)$ tidak menyebabkan reaksi simpang lain (Tabel. 4).

\section{Diskusi}

Subjek penelitian adalah pasien rinitis alergika berusia 6-15 tahun, usia rerata 8,641 tahun (Tabel 1), terdiri dari 47 (61\%) anak laki-laki, dan 30 (39\%) anak perempuan. Pengambilan batas usia pasien termuda pada penelitian ini yaitu 6 tahun, karena dianggap usia tersebut cukup baik untuk menjawab beberapa pertanyaan penilaian gejala klinis dan juga melihat prevalensi pada umumnya banyak ditemukan pada usia sekolah, 15\% - 40\% terjadi pada usia 6-14 tahun., 314 Diagnosis rinitis alergika ditegakkan apabila terdapat gejala beringus, bersin, hidung tersumbat, dan gatal di hidung. Sebelum diberikan pengobatan pasien mendapat pemeriksaan EKG, semua subjek penelitian mempunyai hasil EKG normal.

Sebagian besar pasien $(70,1 \%)$ memiliki skala penilaian hasil pengobatan baik dan $26 \%$ memiliki skala penilaian hasil pengobatan sangat baik. Maka persentase pasien yang memenuhi skala penilaian sangat baik dan baik yaitu 96,1\% (>72\%), dapat disimpulkan hasil pengobatan kombinasi terfanadin dan pseudoefedrin pada rinitis alergika efektif. Efektivitas penggunaan kombinasi terfenadin dan pseudoefedrin dalam pengobatan rinitis alergika dibuktikan juga oleh Panda dkk ${ }^{10}$ dalam penelitian- 
nya. Dilaporkan bahwa kombinasi terfenadin dan pseudoefedrin lebih efektif 72,73\% (jumlah pasien dengan skala sangat baik dan baik dari hasil pengobatan) dibandingkan penggunaan terfenadin saja 47,37\% (jumlah pasien dengan skala sangat baik dan baik) dalam menghilangkan gejala klinis rinitis alergika.

Terfenadin dapat menghambat pelepasan histamin dan prostaglandin pada rangsang nasal, yang merupakan mediator inflamasi menyebabkan gejala klinis rinitis alergika fase akut. ${ }^{16}$ Pemberian terfenadin berhasil baik dalam mengatasi gejala rinitis alergika fase akut, seperti semua pasien pada penelitian ini yang datang dengan gejala klinis pada fase akut.

Pemeriksaan EKG menunjukkan interval Q-Tc antara sebelum dan sesudah pengobatan tidak terdapat perbedaan, sesuai dengan pada penelitian sebelumnya, dilaporkan bahwa tidak ditemukan pemanjangan interval Q-Tc pada pemberian terfenadin pada anak rinitis alergika dengan pemakaian tunggal. Namun, terfenadin akan menyebabkan pemanjangan interval Q-T dan Q-Tc bila diberikan bersamaan dengan pemberian antibiotik golongan makrolid. ${ }^{12}$ Penelitian lain ${ }^{11}$ juga melaporkan bahwa tidak ditemukan perbedaan interval Q-Tc (antara sebelum dan sesudah pengobatan) pada pemakaian terfenadin saja, bila terfenadin diberikan bersamaan dengan obat anti jamur (ketokonazol) akan menimbulkan pemanjangan interval Q-T dan Q-Tc yang bermakna.

Reaksi simpang lain yang ditemukan selama pengobatan pada penelitian ini yaitu mual $(1,3 \%)$, mulut kering $(2,6 \%)$ dan pusing $(1,3 \%)$, tetapi sebagian besar pasien menyatakan tidak ada reaksi simpang lain yang ditemukan (94,8\%). Reaksi simpang tersebut kemungkinan merupakan efek pemakaian kombinasi terfenadin dan pseudoefedrin. Beberapa reaksi simpang terfenadin yaitu pusing, lesu, penglihatan kabur, euforia, gugup, gelisah, insomnia, dan vertigo. Reaksi simpang pemakaian pseudoefedrin di antaranya dapat meyebabkan pusing, nyeri kepala, mual dengan atau tanpa muntah, insomnia takikardi, dan mulut kering. ${ }^{4,5}$

Efektivitas atau keamanan suatu penelitian uji klinis selain ditentukan oleh kasus juga diperlukan suatu kontrol sebagai pembanding dalam melakukan intervensi, sehingga hasil penelitian atau intervensi yang dilakukan benar-benar merupakan hasil intervensi pada penelitian tersebut. Maka diperlukan penelitian lanjutan dengan mempergunakan kelompok pembanding.

\section{Kesimpulan}

Pengobatan kombinasi terfenadin dan pseudoefedrin pada anak rinitis alergika selama 5 hari terbukti efektif dan aman dalam mengurangi gejala rinitis alergika. Sebagian besar pasien menunjukkan hasil pengobatan baik dan sangat baik 96,1\%. Sebagian besar pasien menyatakan tidak merasakan adanya reaksi simpang lain dan tidak ditemukan efek kardiotoksik yang dideteksi engan pemeriksaan EKG.

\section{Daftar Pustaka}

1. Sienra-Mongo JJL, Gazca-Aguilar A, Del Rio-Navaro B. Double blind comparison of cetirizine and loratadine in children ages 2 to 6 years with perennial allergic rhinitis. Am J Ther 1999; 6:149-55.

2. Day JH, Briscoe MP, Clark RH, Ellis AK, Gervais P. Onset of action and efficacy of terfenadine, astemizole, cetirizine, and loratadine for the relief of symptoms of allergic rhinitis. Ann Allergy Asthma Immunol 1997; 79:163-72.

3. Lai L, Casale TB, Stokes J. Pediatric allergic rhinitis: Treatment. Immunol and Allergy Clin of North Am 2005; 25:31-9.

4. Sjamsudin U, Dewoto H. Histamin dan anti alergi. Dalam: Ganiswara S, Setiabudy R, Suyatno F, Purwantyastuty, penyunting. Farmakologi dan Terapi. Jakarta: Bagian Farmakologi FKUI; 1996. h. 248-56.

5. Gentile DA, Friday GA, Skoner DP. Management of allergic rhinitis. Antihistamine and decongestant. Immunol and Allergy Clin of North Am_2000; 20:335-68.

6. Sundaru H. Terapi kombinasi loratadin dan psudoefedrin pada rinitis alergik. Disampaikan pada Jakarta allergy and clinical immunology meeting 2001. Jakarta: 16-17 Juni, 2001.

7. Georgitis JW. Onset-of-action for antihistamine and decongestant combinations during an outdor challenge. Ann Allergy Asthma Immunol 2000; 84:451-9.

8. Sussman GL, Mason J, Comton D, Stewart J, Ricard N. The efficacy and safety of fexofenadine HCL and pseudoephedrine, alone and in combination, in seasonal allergic rhinitis. J Allergy Clin Immunol 1999; 104:100-6.

9. Corren J, Harris AG, Aaronson D, Beacher W, Berkowitz R, Bronsky E, dkk. Efficacy and safety of loratadine plus pseudoephedrine in patients with sea- 
sonal allergic rhinitis and mild asthma. J Allergy Clin Immunol 1997; 100:781-8.

10. Panda NK, Mann SBS. Comparative efficacy and safety of terfenadine with pseudoephedrine and terfenadine alone in allergic rhinitis. Otolaryngol Head Neck Surg 1998; 118:253-5.

11. Woosley RL, ChenY, Freiman JP, Gillis RA. Mechanism of the cardiotoxic actions of terfenadine. JAMA 1993; 269:1532-6.

12. Delgado LF, Pferferman A, Sole D, Naspitz CK. Evaluation of the potential cardiotoxicity of the antihistamines terfenadine, astemizole, loratadine, and cetirizine in atopic children. Ann Allergy Asthma Immunol 1998; 80:333-7.
13. Honig PK, Wortham DC, Zamani K, Conner DP, Mullin JC, Cantilena LR. Terfenadine-ketoconazole interaction. JAMA 1993; 269:1513-8.

14. Skoner DP. Allergic rhinitis: Definition, epidemiology, pathophisiology, detection, and diagnosis. J Allergy Clin Immunol 2001; 108:S2-8.

15. Ricketti AJ. Allergic rhinitis. Dalam: Patterson R, Grammer LC, Greenberger P, penyunting. Allergic diseases. Edisi ke-5. Philadelphia: Loppincott-Raven; 1997. h. 183-204.

16. Simon FER, Simon KJ. Antihistamines. Dalam: Middleton E Jr, Reed CE, Ellis EF, Adkinson NF, Yunginger JW, Busse WW, penyunting. Allergy. Edisi ke-4. Toronto: Mosby; 1993. h. 856-92. 